Original Research Paper

\title{
Stock Market Development and Economic Growth in SADC Region
}

\author{
${ }^{1}$ Sanderson Abel, ${ }^{2}$ Nzwirashe Magomana, ${ }^{2}$ Beatrice Makamba and ${ }^{4}$ Pierre Le Roux \\ ${ }^{I}$ Department of Agricultural Economics and Development, Midlands State University, Zimbabwe \\ ${ }^{2,3}$ Department of Education, Great Zimbabwe University, Zimbabwe \\ ${ }^{4}$ Department of Economics, Nelson Mandela, South Africa
}

Article history

Received: 22-10-2020

Revised: 11-02-2021

Accepted: 20-02-2021

Corresponding Author:

Sanderson Abel

Department of Agricultural

Economics and Development,

Midlands State University,

Zimbabwe

Email: abels@staff.msu.ac.zw

\begin{abstract}
The study investigates the relationship between stock market development and economic growth in the Southern African Development Community (SADC) region for the period 1993-2017. The controversy around the stock market development and economic growth nexus is of concern to the SADC which has been experiencing retarded growth while their stock markets are at different levels of development. To establish the relationship among variables of interest, the study used the Auto Regressive Distributive Lag (ARDL) model. The results revealed that there is bi-directional causality both in the short and long run between stock market development and economic growth. The findings further show that trade openness and investment significantly determine stock market development and economic growth in the long run. The result calls for SADC member countries to develop policies that enhance economic growth as well as improving stock market development.
\end{abstract}

Keywords: Stock Market, Economic Growth, SADC, ARDL, Causality

\section{Introduction}

There has been great interest in investigating the relationship between financial sector development and economic growth. The theoretical genesis of this association is found in the early discussions of Bagehot (1873). He contended that the financial system plays an important role in enabling the mobilization of capital and economic growth. The argument was stretched by (Schumpeter, 1911; Robinson, 1952; Hicks, 1969) among others, who argued that the services provided by financial institutions are key drivers of innovation and economic growth. Similar studies flourished in the 1990 and $2000 \mathrm{~s}$ (Osaseri and Osamwonyi, 2019; Qamruzzaman and Wei, 2018; Levine, 1997; Dailami and Atkin, 1990).

The contentious issue emanating from the debate on nexus between stock market development and economic growth centres around the direction of causality between stock market development and economic growth (Kapaya, 2020; Osaseri and Osamwonyi, 2019; Qamruzzaman and Wei, 2018; Maposa and Muma, 2017; Popoola et al., 2017; Tsaurai, 2016). The view that stock market developments drive economic growth is based on the understanding that development on the stock market feeds into consumption and investment decisions made by individuals and firms (Maposa and Muma, 2017; Popoola et al., 2017). This implicitly assumes that consumers' confidence and their spending drives economic growth.
Stock markets play a strategic role in allocating capital to firms which impact the real economy. Debt finance is scarce in developing countries. Bank loans are limited to a few corporates and individual investors. The financial sector including stock markets affect long run economic growth through capital accumulation and rate of technological progress (Alshammary, 2014). Greenwood and Jovanovic (1990) argue that stock market liquidity promotes long-term economic growth in developing countries. Levine (1997) opines that stock market liquidity and well-developed banks promotes economic growth. Of great interest is the fact that greater stock market liquidity leads to faster growth no matter what the level of banking development. On the other hand, banking sector development leads to faster economic growth regardless of the level of stock market liquidity. Each of these components (banks and stock markets) of the financial system is an independent strong predictor of growth. Given the aforementioned, being an important support of the economy, the stock market plays an essential part in the growth of industry and commerce.

The Southern African Development Community (SADC) has a mandate of ensuring an all-inclusive development among member countries. The growth rates in SADC region has been retarded while the stock markets are not very developed except for South Africa and Zimbabwe. The SADC member countries have been facing enormous challenges raising capital for 
development post the global financial crisis. The twin challenge of retarded economic growth and lack of developed stock markets brings to the fore the role of the stock markets in enhancing economic growth in this region. In light of this dilemma, the current study seeks to evaluate the causal nature of the relationship between economic growth and stock market development. The two variables are important to SADC countries since they form part of the macroeconomic convergence matrix. The current study therefore looks at the nexus between stock market development and economic growth in the SADC region.

\section{Background to SADC Stock Markets}

The majority of countries in Africa adopted financial sector reforms to liberalise their financial systems as well as to enhance their non-bank financial institutions and capital markets (Kapaya, 2020; Osaseri and Osamwonyi, 2019; Qamruzzaman and Wei, 2018; Naik and Padhi, 2015). The rationale behind the reforms was the desire to expand financial intermediation through non-bank financial institutions and stock markets so as achieve sustained economic growth. The development of stock markets in developing countries is also suggestive of the conviction in a link between stock market development and economic growth. The development and growth of stock markets in developing nations has therefore, been fast in recent times, particularly in Africa.

There was deliberate policy moves by a number of African countries to create stock markets in the 1990s. Before adopting this move, stock markets existed only in Egypt, South Africa, Tunisia, Kenya, Zimbabwe and Nigeria. The early to mid-1990s witnessed rapid growth in the number of stock markets in Africa. The coming on board of these stock market changed the structure of the financial systems in most African countries, now characterized not only by money markets, but also capital markets. There is little knowledge about the degree of development of most African stock markets. This has been hindering research on how stock markets in Africa has been performing. There are a number of stock market development indicators, yet there has been hardly any systematic effort at documenting stylized facts about African stock markets (Komla and Amo, 2007).
The Southern African Development Community (SADC) is a Regional Economic Community comprised of 16 Member States. The block was established in 1992. It is dedicated to regional integration and poverty eradication within Southern Africa through economic development and ensuring peace and security.

As part of the SADC regional financial system, capital markets are an important part of the region. The requirements for finances in the region are massive. These finances are required for long-term infrastructural projects and social development programmes. These are usually raised by capital markets through stocks, bonds and other investments offerings. Financing of these projects and programmes in SADC is important as the block seeks to attain a status of a modern and integrated economy. This requires member countries to attract private sector investment. This has led to the inclusion of the protocol on finance and investment among the various protocols of the block. The SADC seeks to establish harmonised securities' market throughout the region that can attract investment and allow the regional economy to compete on a global scale. To this end the region has agreed on harmonisation of stock markets listing requirements, shared research and information management on market surveillance, regulation and investor encouragement.

Table 1 shows the various statistics pertaining to the stock exchanges in the SADC region. The table reflects that the stock markets have listed corporates ranging from 14 to above 400. This basically reflects that the different economies in the SADC are too heterogeneous with countries such as South Africa being big economies with a great deal of listed corporates. There are also smaller countries such as Malawi which are very small and have small exchanges with only 14 corporates listed. The implication of the number of corporates have an effect on the liquidity and efficiency of the stock exchanges. Those countries with a big number of listed firms are more likely to be efficient and liquid. This then provides investors with increased options of where to put their investments.

The results show that save for the South African stock market, all other exchanges are undervalued as reflected by their market capitalisation as a proportion of GDP of less than 100. The stock turnover ratio measures the extent shares exchange hands. It shows the degree to which shares are converted into revenues. South Africa seems to be doing well in the SADC region in terms of stock turnover with a ratio of $40.93 \%$.

Table 1: SADC (Stock Market Statistics, 2017)

\begin{tabular}{|c|c|c|c|c|}
\hline Country & Listed companies & $\begin{array}{l}\text { Market capitalisation } \\
\text { ( } \% \text { of GDP) }\end{array}$ & $\begin{array}{l}\text { Value traded } \\
\text { (Million-US \$) }\end{array}$ & $\begin{array}{l}\text { Stock traded: } \\
\text { Turnover Ratio (\%) }\end{array}$ \\
\hline Botswana & 44 & 23.8 & $\$ 135.60$ & 2.71 \\
\hline Namibia & 29 & 11.8 & $\$ 494.51$ & 0.34 \\
\hline Malawi & 14 & 20.0 & $\$ 16.18$ & 1.57 \\
\hline Zimbabwe & 64 & 42.8 & $\$ 448.20$ & 11.31 \\
\hline Tanzania & 25 & 33.0 & $\$ 32.38$ & 0.39 \\
\hline Zambia & 24 & 52.8 & $\$ 68.32$ & 0.73 \\
\hline South Africa & 403 & 159.3 & $\$ 408628.96$ & 40.93 \\
\hline
\end{tabular}

Sources: SADC website 


\section{Literature Review}

Several empirical studies have focused on probing the association between stock market and economic growth, reaching varying conclusions. Even studies that have looked at the same country or region have come up with different findings. These findings can be categorised into four. These are stock market development-led economic growth, economic growth-led stock market hypothesis, the feedback effect and the neutrality hypothesis.

Kapaya (2020) studied the causal relationship between stock markets and economic growth in Tanzania. The study applied the Autoregressive Distribute Lag Model (ARDL) with bound testing procedures. The findings of the study showed that stock market development granger causes economic growth in both the short and long run.

Osaseri and Osamwonyi (2019) evaluated the relationship between stock market development and economic growth in BRICS for the period 1994-2015 using the panel least squares estimation method. They found that the stock market development significantly impacts economic growth. The study established a positive correlation between stock market development and economic growth. They recommended BRICS countries should focus on strengthening their economic systems.

Qamruzzaman and Wei (2018) studied the connection among economic growth, financial innovation and stock market development in Bangladesh for the period 1980-2016. The study adopted the Autoregressive Distributed Lagged (ARDL) bounds testing approach and granger causality test to ascertain the long run and causal relationship among the variables respectively. The ARDL bounds testing approach established that there is long-run relationship among the variables. The Granger-causality test found that there is the bi-directional causality in both the long and short run.

Maposa and Muma (2017) studied the nexus between financial development and economic growth in Zimbabwe. The study used the vector error correction model. A positive relationship between the stock market and economic growth was established in both the short and long run. They established that financial sector development is critical for sustainable economic development.

Popoola et al. (2017) undertook a short and long run causality test between stock market development and economic growth in Nigeria. A long run relationship was established between the stock market performance and economic growth. Specifically, a negative significant relationship between an all-share index and economic growth was established. The study also found that economic growth granger causes stock market performance.

Musharavati (2017) examined the nexus between financial development and economic growth in Zimbabwe. The study employed time series analysis. The results revealed that causality results were dependent on how financial development was measured.
In a study of Belgium, (Tsaurai, 2016) evaluated the nexus between stock market development and economic growth. The study applied the ARDL approach with annual time series data for the period 1988-2012. GDP per capita was adopted as a proxy for economic growth and stock market development was approximated by stock market capitalization as a ratio of GDP. The results found no evidence of long run causality running from stock market development to economic growth.

Auckbarally and Subadar (2015) applied the panel data method to ascertain the relationship between stock market development and economic growth among SADC countries for the period 1980-2011. The study established that there is a strong association between stock market development and economic growth. The results supported the argument that economic growth can be boosted by a developed and functional stock market.

Ishioro (2013) evaluated the causality relationship between stock market development and economic growth in Zimbabwe for the period running from 1990 to 2010. The study used the long-run Granger noncausality estimation technique. The results of the study supported the supply leading hypothesis which was shown by a bi-directional causality between economic growth and stock market development.

Simwaka et al. (2012) examined causation between financial development and economic growth in Malawi. They applied the Autoregressive Distributed Lag (ARDL) model to search for the relationship. The results established that there is a positive and significant relationship between financial development and economic growth in the long run. Granger causality tests found evidence of economic growth driving financial development.

Petros (2012) evaluated the relationship between stock market development and economic growth in Zimbabwe for the period 1991-2017. The study used the Auto Regressive Distributive Lag (ARDL) and Error Correction Model (ECM) model. The results found that stock market development positively impacted economic growth both in the short and long run in Zimbabwe.

Alajekwu and Achugbu (2012) probed the impact of stock market development on economic growth in Nigeria. They applied the ordinary least squares method using time series data for the period 1994-2008. The study found evidence of weak negative correlation between stock market capitalization and stock market development. Stock market turnover was found to have a significant positive impact on economic growth in Nigeria.

Zivengwa et al. (2011) evaluated the causality between stock market development and economic growth in Zimbabwe for the period 1980-2008. The study adopted the Vector Autoregressive (VAR) and Granger Causality Tests to explore the relationships among the variables. The study found evidence of uni-directional causality running from stock market development to economic growth. The study also established evidence of an indirect 
transmission mechanism through the effect of stock market development on investment.

\section{Research Methodology}

The methodology of the study is presented in this section. This consists of study data, model specification and justification of the variables employed.

\section{Study Data}

The study relied on secondary data which was compiled from different sources such as Word Bank Development Indicators, African Security Exchange Association (ASEA) and Global Financial Development. The study covered 11 SADC countries; Mozambique, Swaziland, Seychelles, South Africa, Zambia, Zimbabwe, Botswana, Mauritius, Malawi, Tanzania and Namibia. The remaining four nations where dropped due to data unavailability.

\section{Model Specification and Methodology}

The study specifies the following general model to capture the relationships among stock market development, economic growth, investment and trade openness:

$$
G D P_{i t}=f\left[S M D_{i t}, I N V_{i t}, T R A D E_{i t}\right]
$$

The current study adopts the approach which were used by other studies (Ruwaydah and Ushad, 2015; Seetanah et al., 2008). The econometric model adopted is specified as:
$G D P_{i t}=\beta_{0}+\beta_{1} S T M D_{i t}+\beta_{2} I N V_{i t}+\beta_{3} T R A D E_{i t}+\varepsilon_{i t}$

The Autoregressive Distribute Lag model (ARDL) as expounded (Pesaran et al., 2001) is adopted. The ARDL model is founded on an Ordinary Least Square (OLS) method which can be used in situations of non-stationary series as well as in cases of mixed order of integration (Shrestha and Bhatta, 2018).

The ARDL approach is perceived to be smarter than other methods in its class. The ARDL method has the following characteristics. It can be applied in cases of small or finite samples consisting of 30 or more observations (Ghatak and Siddiki, 2001). The method can be used in cases where the variables are stationery at different levels as long there are not integrated of order greater than one. It caters for serial correlation and the indigeneity problem when modelled with appropriate lags (Pesaran et al., 2001). Both the long run and short run cointegration relations can be estimated using the ARDL method (Pesaran et al., 2001).

The study uses four variables of interest and these are Stock Market Development (SMD), economic Growth (GDP), Trade openness (TRADE) and total Investment (INV). Trade openness and total investment are included in the model as control variables and are important in defining growth imperatives as discussed in Table 2. In the study the ARDL model in Eq. (3) is specified. The analysis conceptualizes four models/equations with the dependent variables; GDP, SMD, INV and TRADE:

$$
\begin{aligned}
\Delta G D P_{i t}= & \alpha_{o}+\alpha_{1} G D P_{t-1, i}+\alpha_{2} S M D_{t-1, i}+\alpha_{3} I N V_{t-1, i}+\alpha_{4} T R A D E_{t-1, i}+\sum_{i=1}^{p} \gamma_{i} \Delta G D P_{t-1} \\
& +\sum_{i=0}^{p} \vartheta_{i} \Delta S M D_{t-1}+\sum_{i=0}^{p} \mu_{i} \Delta I N V_{t-1}+\sum_{i=0}^{p} \tau_{i} \Delta T R A D E_{t-1}+\varepsilon_{i t} \\
\Delta S M D_{i t}= & \alpha_{o}+\alpha_{1} S M D_{t-1, i}+\alpha \beta_{2} G D P_{t-1, i}+\alpha_{3} I N V_{t-1, i}+\alpha_{4} T R A D E_{t-1, i}+\sum_{i=1}^{p} \gamma_{i} \Delta S M D_{t-1} \\
& +\sum_{i=0}^{p} \vartheta_{i} \Delta G D P_{t-1}+\sum_{i=0}^{p} \mu_{i} \Delta I N V_{t-1}+\sum_{i=0}^{p} \tau_{i} \Delta T R A D E_{t-1}+\varepsilon_{i t} \\
\Delta I N V_{i t}=\alpha_{o} & +\alpha_{1} I N V_{t-1, i}+\alpha_{2} S M D_{t-1, i}+\alpha_{3} G D P_{t-1, i}+\alpha_{4} T R A D E_{t-1, i}+\sum_{i=1}^{p} \gamma_{i} \Delta I N V_{t-1} \\
& +\sum_{i=0}^{p} \vartheta_{i} \Delta S M D_{t-1}+\sum_{i=0}^{p} \mu_{i} \Delta G D P_{t-1}+\sum_{i=0}^{p} \tau_{i} \Delta T R A D E_{t-1}+\varepsilon_{i t} \\
\Delta T R A D E_{i t}= & \alpha_{o}+\alpha_{1} T R A D E_{t-1, i}+\alpha_{2} S M D_{t-1, i}+\alpha_{3} I N V_{t-1, i}+\alpha_{4} G D P_{t-1, i}+\sum_{i=1}^{p} \gamma_{i} \Delta T R A D E_{t-1} \\
& +\sum_{i=0}^{p} \vartheta_{i} \Delta S M D_{t-1}+\sum_{i=0}^{p} \mu_{i} \Delta I N V_{t-1}+\sum_{i=0}^{p} \tau_{i} \Delta G D P_{t-1}+\varepsilon_{i t}
\end{aligned}
$$


Table 2: Data Sources and justification

\begin{tabular}{|c|c|c|c|}
\hline Variable & Definition and Justification & Measurement unit & Source \\
\hline $\begin{array}{l}\text { Gross Domestic Product } \\
\text { growth (GDP) }\end{array}$ & $\begin{array}{l}\text { Generally speaking, the stock market reflects the economic } \\
\text { conditions of an economy. In times of economic boom, } \\
\text { output increases and most companies experience increased } \\
\text { profitability. The increased profit makes the firms shares } \\
\text { attractive. Companies can declare large dividends to } \\
\text { shareholders. A long period of economic growth benefits } \\
\text { corporates as their shares continue to increase. }\end{array}$ & Percentage & $\begin{array}{l}\text { Word bank development } \\
\text { indicators }\end{array}$ \\
\hline Stock Market & Stock market development can be measured in two ways & Ratio & African Security Exchange \\
\hline Development (SMD) & $\begin{array}{l}\text { using size or liquidity (Rousseau and Wachtel, 2000). } \\
\text { Size incorporates the concentration ratio that is the market } \\
\text { capitalization ratio whilst liquidity involves the total value } \\
\text { of shares ratio, trading value ratio and turnover ratio. } \\
\text { The current study adopts the size definition }\end{array}$ & & Association (ASEA) \\
\hline Trade openness & $\begin{array}{l}\text { Openness of the economy enhances stock market } \\
\text { development. Openness of an economy attracts foreign } \\
\text { and domestic investment into the financial system. This } \\
\text { is measured as total exports and imports (\% of GDP). }\end{array}$ & Percentage & $\begin{array}{l}\text { Word bank development } \\
\text { indicators }\end{array}$ \\
\hline Investment (INV) & $\begin{array}{l}\text { The rate of investment is regarded as the degree of domestic } \\
\text { investment in an economy, (Mbuka, 1993) and gross capital } \\
\text { formation is used as a proxy for the investment rate. There is } \\
\text { a positive relationship between investment and economic growth } \\
\text { as espoused by (Solow, 1956) hence the expected sign is positive. }\end{array}$ & US dollars & $\begin{array}{l}\text { Word bank development } \\
\text { indicators }\end{array}$ \\
\hline
\end{tabular}

where, $\alpha_{o}$ is a constant element and $\varepsilon_{i t}$ is the process that is white noise. In this method, the ARDL estimates ( $p$ $+1)^{k}$ number of regressions to obtain optimal lag length. The current study follows a certain order: investigation of the integrational properties of the variables, followed by an ARDL cointegration analysis which is succeeded by causality analysis.

\section{Results Presentation}

This section presents the results of the study. It looks at the ARDL long run and error correction mechanism results. Before looking at the main results, this section will present the descriptive statistics of the variables, correlation matrix and the unit root test results.

The descriptive statistics of the dependent and explanatory variable are summarised in Table 3. These include the statistical mean, minimum, maximum and standard deviation and the number of observations. The total number of observations considered in the study are 275 covering 25 years for the 11 countries.

The data under consideration is balance panel data. There are four variables under consideration; SMD, INV, TRADE and GDP. The data shows that there is less variability on INV and GDP as compared with SMD and TRADE. This is shown by the lower standard deviation for INV and GDP. Table 3 shows that the average SMD value was 23.59 and ranged between -22.85 and 117.01 . Economic growth rates in the 11 countries over the study period was $2.21 \%$ with the maximum growth rate and minimum growth rate experienced over the period of 23.03 and $-19.06 \%$ respectively.

Multicollinearity refers to the availability of one or more linear relationships among some or all explanatory variables of a regression model. Multicollinearity leads to unbiased estimates while evaluation of the relative strength of the explanatory variables and their joint effect are not reliable. The challenge of multicollinearity manifests if the correlation between independent variables is above 0.8 (Abel and Le Roux, 2016). Table 4 shows that there is moderate correlation among the GDP, INV, SMD and TRADE. The result suggests that all the variables can be used in regression analysis without facing the problem of multicollinearity.

The Levin, Lin, Chu test and the Im, Pesaran, Shin test are applied to identify the order of integration of the variables. The application of the two methods was meant to ensure that the variables are not integrated of order greater than one which is a prerequisite of the ARDL method. The results of the unit root test are presented in Table 5. The variables GDP and Openness are found to be stationary in their levels hence they are integrated of order zero. On the other hand, SMD and INV are integrated of order one.

The results of the unit root test allow the study to proceed to empirically analyse the long run relationship and short run dynamic interaction among the variables using the ARDL model. The method requires that the variables should be integrated of order zero, one or mixture of the two but should not be integrated of order 2 and above.

Based on automatic lag selection, the best model had 4 lags in independent and 4 lags in the dependent variable, hence we have the ARDL long run model and the short run ECM ARDL $(4,4,4,4)$ for both economic growth and stock market development as shown in Table 6. The lag 
length of the ARDL ECM was automatically set with 4 lags for the dependent variable and 4 lags for independent variables.

The short run error correction term for the GDP and SMD models are significant and has the correct sign signifying cointegration. This implies that there is a long run relationship among the variables. The existence of the long run relationship between the variables GDP, SMD, TRADE and INV suggests that there must be granger causality in at least one direction (Odhiambo, 2010).

The coefficients of lagged error correction term measures how the dependent variable adjusts to the previous period's deviation from long-run equilibrium. Table 6 confirms that the estimated lagged error correction term in the GDP equation has the expected negative sign and it is statistically significant at one percent level. The speed of convergence to equilibrium of $91 \%$, implies that the stock market development influences economic growth in the long-term. This implies that $91 \%$ of the shocks experienced in the current period are corrected in the next period. The results are in support of the (Zivengwa et al., 2011). The results are buttressed by the significant coefficient of the SMD. A $1 \%$ increase in stock market leads to a $0.07 \%$ increase in economic growth.

On the other hand, the error correction coefficient of stock market development equation is found to be statistically significant at one percent level, suggesting economic growth influences the stock market development in the long-term. The coefficient has the expected negative sign which is significant. The speed of adjustment is $114 \%$, implying that $114 \%$ of the shocks experienced in the current period are corrected in the next period. The long run results also show that an increase in economic growth leads to a decline of the stock market. A $1 \%$ increase in economic growth leads to a $1.32 \%$ decline in stock market development.

The results further show that trade openness and investment significantly determine stock market development and economic growth. Both trade openness and investment have a negative significant influence on economic growth. In other words, a $1 \%$ increase in trade openness and investment leads to a decline of economic growth of 0.16 and $0.09 \%$ respectively. The results are counter intuitive since the two variables are supposed to be growth imperatives. On the other hand, trade openness has a positive significance on stock market development while investment has a negative and significant impact on growth.

Table 7 shows the results of the ARDL regression results with Trade and INV as the dependent variables. Both models have maximum lags of 4 for the dependent and independent variables hence we have ECM ARDL (4, 4, 4, 4). The TRADE regression model shows that there is no cointegration among the variables as the t-statistic for the error correction term is insignificant implying no long run relationship among the variables. On the other hand, the error correction term for the INV regression equation confirms that there is long run relationship among the variables. The results show that investment, stock market development and GDP significantly determine trade openness hence their coefficients are significant.

Having established long run causal relation, the study further presents the short run Granger causality results for the short run relationship between all macroeconomic variables. Short-term Granger causality test is employed on ECM so as to identify the short-run causal relationship among the variables. The Wald-statistics of short-run test for causality are summarized in Table 8 .

Table 3: Descriptive statistics

\begin{tabular}{lrrrr}
\hline & SMD & \multicolumn{1}{c}{ INV } & TRADE & GDP \\
\hline Mean & 23.59 & 23.04 & 86.94 & 2.21 \\
Median & 16.65 & 22.09 & 79.66 & 2.33 \\
Maximum & 117.01 & 55.36 & 225.02 & 23.03 \\
Minimum & -22.85 & 1.53 & 23.98 & -19.06 \\
Std. Dev. & 25.32 & 8.82 & 38.88 & 4.32 \\
Observations & 275.00 & 275.00 & 275.00 & 275.00 \\
\hline
\end{tabular}

Source: Own computation

Table 4: Correlation matrix

\begin{tabular}{lcccc}
\hline & SMD & INV & TRADE & GDP \\
\hline SMD & 1 & & & \\
INV & -0.1818 & 1.0000 & & \\
TRADE & 0.3540 & 0.2566 & 1.000 & \\
GDP & 0.2281 & 0.2273 & 0.098 & 1 \\
\hline
\end{tabular}

Source: Own computation

Table 5: Panel unit root test

\begin{tabular}{|c|c|c|c|c|c|c|}
\hline \multirow{3}{*}{$\frac{\text { Variable }}{\text { GDP }}$} & \multirow{3}{*}{$\begin{array}{l}\text { Test } \\
\text { level }\end{array}$} & \multirow{3}{*}{ Levin, Lin, Chu } & \multicolumn{2}{|c|}{ Im, Pesaran, Shin } & \multicolumn{2}{|c|}{ Level of Integration } \\
\hline & & & & -------- & ----- & \\
\hline & & & 0.0000 & 6.3262 & 0.0000 & $\mathrm{I}(0)$ \\
\hline & 1st difference & 9.4204 & 0.0000 & 13.3188 & 0.0000 & \\
\hline \multirow[t]{2}{*}{ SMD } & level & 0.9239 & 0.1777 & 1.4733 & 0.0703 & $\mathrm{I}(1)$ \\
\hline & 1st difference & 6.0726 & 0.0000 & 9.6465 & 0.0000 & \\
\hline \multirow[t]{2}{*}{ INV } & level & 1.5912 & 0.0558 & 1.3549 & 0.0877 & $\mathrm{I}(1)$ \\
\hline & 1st difference & 4.2023 & 0.0000 & 6.9399 & 0.0000 & \\
\hline \multirow[t]{2}{*}{ TRADE } & level & 2.0879 & 0.0018 & 2.3489 & 0.0094 & $\mathrm{I}(0)$ \\
\hline & 1st difference & 5.5768 & 0.0000 & 7.2585 & 0.0000 & \\
\hline
\end{tabular}

Source: Own computation 
Sanderson Abel et al. / Journal of Social Sciences 2021, Volume 17: 89.97 DOI: 10.3844/jssp.2021.89.97

Table 6: ARDL long run and short run results (GDP and SMD)

\begin{tabular}{|c|c|c|c|c|}
\hline \multirow[b]{2}{*}{ Variable } & \multicolumn{4}{|l|}{ Long run equation } \\
\hline & Dependent variable: GDP coefficient & Dependent variable: SMD t-statistic & Coefficient & t-statistic \\
\hline$\overline{\mathrm{INV}}$ & -0.164370 & -2.0987 & -0.059805 & -1.216165 \\
\hline SMD & 0.070921 & 5.31324 & & \\
\hline TRADE & -0.098949 & -6.9833 & 0.137752 & 3.302162 \\
\hline GDP & & & -1.322216 & -12.11590 \\
\hline \multicolumn{5}{|c|}{ Short Run Equation } \\
\hline $\mathrm{ECT}(-1)$ & -0.913823 & -2.805807 & -1.136667 & -4.429375 \\
\hline $\mathrm{D}(\mathrm{GDP})$ & & & 0.427132 & 0.481606 \\
\hline $\mathrm{D}(\operatorname{GDP}(-1))$ & 0.009660 & 0.056738 & 0.696919 & 1.381826 \\
\hline $\mathrm{D}(\operatorname{GDP}(-2))$ & -0.196655 & -1.725140 & -0.555517 & -0.503980 \\
\hline $\mathrm{D}(\operatorname{GDP}(-3))$ & & & 0.002852 & 0.005582 \\
\hline D(INV) & 0.144733 & 0.780211 & -1.152339 & -1.017392 \\
\hline $\mathrm{D}(\mathrm{INV}(-1))$ & 0.000770 & 0.002887 & -0.813124 & -0.696871 \\
\hline $\mathrm{D}(\mathrm{INV}(-2))$ & -0.031892 & -0.183626 & -1.103319 & -0.836793 \\
\hline $\mathrm{D}(\mathrm{INV}(-3))$ & -0.003763 & -0.023276 & 0.255468 & 0.502310 \\
\hline $\mathrm{D}(\mathrm{SMD})$ & -0.236757 & -2.616798 & & \\
\hline $\mathrm{D}(\operatorname{SMD}(-1))$ & -0.241862 & -2.437348 & 0.078778 & 0.305164 \\
\hline $\mathrm{D}(\operatorname{SMD}(-2))$ & -0.312872 & -3.541195 & 0.332421 & 1.460983 \\
\hline $\mathrm{D}(\operatorname{SMD}(-3))$ & -0.089072 & -2.544093 & 0.155852 & 1.055489 \\
\hline D(TRADE) & 0.034692 & 0.485483 & -0.420662 & -1.059219 \\
\hline D(TRADE(-1)) & 0.055246 & 1.232356 & -0.096839 & -0.382000 \\
\hline D(TRADE(-2)) & -0.012659 & -0.294764 & -0.459941 & -1.367527 \\
\hline D(TRADE(-3)) & 0.012379 & 0.286823 & 0.078100 & 0.614544 \\
\hline
\end{tabular}

Table 7: ARDL long run and short run results (Trade and INV)

\begin{tabular}{|c|c|c|c|c|}
\hline \multirow[b]{2}{*}{ Variable } & \multicolumn{4}{|l|}{ Long run equation } \\
\hline & Dependent variable: TRADE Coefficient & Dependent variable: INV t-statistic & Coefficient & t-statistic \\
\hline$\overline{\mathrm{INV}}$ & 1.571696 & 4.88742 & & \\
\hline SMD & & 3.185795 & -0.282663 & -7.913424 \\
\hline TRADE & 0.361868 & & 0.287667 & 11.22967 \\
\hline GDP & 1.630241 & 4.238177 & 0.634723 & 6.380416 \\
\hline \multicolumn{5}{|c|}{ Short Run Equation } \\
\hline ECT(-1) & -0.372827 & -2.494793 & -0.398267 & 0.07777 \\
\hline $\mathrm{D}(\mathrm{GDP})$ & -0.387429 & -0.795738 & -0.194114 & -0.643561 \\
\hline $\mathrm{D}(\mathrm{GDP}(-1))$ & -0.462573 & -1.274139 & -0.066648 & -0.273700 \\
\hline $\mathrm{D}(\mathrm{GDP}(-2))$ & -0.375552 & -0.767685 & -0.020117 & -0.086275 \\
\hline $\mathrm{D}(\mathrm{GDP}(-3))$ & 0.298958 & 0.648330 & -0.022616 & -0.139405 \\
\hline $\mathrm{D}(\mathrm{INV})$ & -0.912002 & -2.389163 & & \\
\hline D(INV(-1)) & -0.818389 & -1.718220 & -0.157723 & -0.986400 \\
\hline $\mathrm{D}(\mathrm{INV}(-2))$ & -0.651967 & -1.488880 & & \\
\hline $\mathrm{D}(\mathrm{INV}(-3))$ & -0.520974 & -2.400946 & & \\
\hline D(SMD) & -0.376746 & -1.019113 & 0.125281 & 0.619402 \\
\hline D(SMD(-1)) & -0.443099 & -1.100839 & 0.124888 & 0.844162 \\
\hline $\mathrm{D}(\operatorname{SMD}(-2))$ & -0.123276 & -0.282998 & 0.266413 & 1.819386 \\
\hline $\mathrm{D}(\mathrm{SMD}(-3))$ & -0.034017 & -0.263514 & 0.299039 & 2.771175 \\
\hline D(TRADE) & 0.032754 & 0.176721 & -0.036945 & -0.394019 \\
\hline $\mathrm{D}(\mathrm{TRADE}(-1))$ & - & - & -0.014320 & -0.244434 \\
\hline D(TRADE $(-2))$ & - & - & -0.121844 & -3.367366 \\
\hline D(TRADE $(-3))$ & - & - & -0.085484 & -1.247584 \\
\hline
\end{tabular}

Source: Own computation

Table 8: Wald test results

\begin{tabular}{lll}
\hline Null hypothesis & Chi-square & P-value \\
\hline SMD-does-not-cause-GDP & $11.04^{* *}$ & 0.0261 \\
GDP-does-not-cause-SMD & $15.49^{* *}$ & 0.0380 \\
INV-does-not-cause-GDP & 3.30 & 0.5076 \\
TRADE-does-not-cause-GDP & 4.41 & 0.3528 \\
INV-does-not-cause-SMD & 4.87 & 0.3006 \\
TRADE-does-not-cause-SMD & 6.62 & 0.1574 \\
\hline
\end{tabular}

The Wald test statistics show that the null hypothesis of the absence of causality from stock market development to GDP is rejected at 5\% level of significance (Table 8). In the same way the causal relationship from GDP to stock market development is also rejected at 5\% level of significance. The results therefore confirm that there is bidirectional causality between stock market development and economic growth in the short run. 


\section{Discussion}

The study investigated the causality relationship between stock market development and economic growth. The study found that there is evidence of long run relationship between stock market development and economic growth. In other words, there is cointegration between the two variables. The results established that there is bidirectional causality between stock market development and economic growth in the long-run. The results are supported by prior studies (Qamruzzaman and Wei, 2018; Auckbarally and Subadar 2015; Ishioro 2013; Alajekwu and Achugbu, 2012) which also found bidirectional causality between stock market development and economic growth.

The short run dynamics between stock market development and economic growth also found evidence of causal relationship between the two variables. This means that there is feedback effect between stock market development and economic growth in the short. This reveals that stock market development increases economic growth while economic growth positively influences stock market development. This then establishes the need for the government to put in place policies that have positive impact on both economic growth and stock market development.

On the other hand, the results show that investment and trade openness do not granger cause economic growth and stock market development in the short run. This then implies economic growth granger causes stock market development and stock market development granger cause economic growth, nothing more or less.

\section{Conclusion}

The study investigated the relationship between stock market development and economic growth in the SADC region. The study established short run and long cointegration between stock market development and economic growth. The study further established that trade openness and investment significantly determine stock market development and economic growth. This implies that economic growth causes stock market development and vice versa both in the short and long run. The results have policy implications in that governments should enact policies that are pro stock market development as well as pro economic growth given the feedback effect among the variables.

\section{Author's Contributions}

Sanderson Abel: Contributed in the conception, design, drafting, acquisition of data, analysis and interpretation of data, reviewing and final approval of the submitted manuscript.

Nzwirashe Rejoyce Magomana: The author contributed in the conception, design, drafting, acquisition of data, analysis and interpretation of data, reviewing and final approval of the submitted manuscript.
Makamba Biatrice Simbisai: Contributed in the conception, design, drafting, acquisition of data, analysis and interpretation of data, reviewing and final approval of the submitted manuscript.

Pierre Le Roux: Contributed to conception, design, drafting, acquisition of data, analysis and interpretation of data, reviewing and final approval of the submitted manuscript.

\section{Ethics}

This article is original and contains unpublished material. The corresponding author confirms that all of the other authors have read and approved the manuscript and no ethical issues involved.

\section{References}

Abel, S., \& Le Roux, P. (2016). An evaluation of the nexus between banking competition and efficiency in Zimbabwe. Studies in Economics and Econometrics, 40(3), $1-20$. https://doi.org/10.1080/10800379.2016.12097301

Alajekwu, U. B., \& Achugbu, A. A. (2012). The role of stock market development on economic growth in Nigeria: A time series analysis. African Research Review, 6(1), 51-70. https://doi.org/10.4314/afrrev.v6i1.5

Alshammary, M. J. (2014). Stock market development and economic growth in developing countries: Evidence from Saudi Arabia. Corporate Ownership \& Control, 11(3), 193-216. https://doi.org/10.22495/cocv11i3c1p6

Auckbarally, R \& Subadar, A.U. (2015) Effects of Stock Market Development on Economic Growth: The Case of SADC Countries Proceedings of the Third Middle East Conference on Global Business, Economics, Finance and Banking (ME15Dubai October Conference), ISBN - 978-1-63102-286-9

Bagehot, W. (1873). Lombard Street: A description of the money market. Scribner, Armstrong \& Company.

Dailami, M., \& Atkin, M. (1990). Stock markets in developing countries: key issues and a research agenda (Vol. 515). World Bank Publications.

Ghatak, S., \& Siddiki, J. U. (2001). The use of the ARDL approach in estimating virtual exchange rates in India. Journal of Applied Statistics, 28(5), 573-583. https://doi.org/10.1080/02664760120047906

Hicks, J. (1969). A theory of economic history (Vol. 9). Oxford: Oxford University Press. https://doi.org/10.2307/2230128

Ishioro, B. O. (2013). Stock market development and economic growth: Evidence from Zimbabwe. Ekonomska Misao i Praksa, (2), 343-360. https://hrcak.srce.hr/112603 
Kapaya, S. M. (2020). Stock market development and economic growth in Tanzania: an ARDL and bound testing approach. Review of Economics and Political Science. https://doi.org/10.1108/REPS-11-2019-0150

Komla, C. A \& Amo, C. Y (2007). Stock Market Development in Sub-Saharan Africa; Critical Issues and Challenges, IMF Working Papers 2007/209, International Monetary Fund.

Levine, R. (1997). Financial development and economic growth: views and agenda. Journal of Economic Literature, 35(2), 688-726. https://www.jstor.org/stable/2729790?seq=1

Maposa, L., \& Muma, F. M. (2017). The Impact of Financial Development on Economic Growth in Zimbabwe: Comparative Analysis of Stock Markets and Commercial Banks. Open Access Library Journal, 4(8), 1-27. https://doi.org/10.4236/oalib.1103808.

Mbuka, J. (1993). Foreign Aid and Economic Growth and Econometric Study of Bangladesh Applied Economics, vol. 24, 541-544. https://doi.org/10.1080/00036849200000067

Musharavati, M. E. (2017). Foreign direct investment and economic growth nexus in Zimbabwe: A cointegration approach, MPRA Paper 77946, University Library of Munich, Germany. https://mpra.ub.unimuenchen.de/77946/

Naik, P. K., \& Padhi, P. (2015). On the linkage between stock market development and economic growth in emerging market economies: Dynamic panel evidence. Review of Accounting and Finance, 14(4), 363-381. https://doi.org/10.1108/RAF-09-2014-0105

Odhiambo, N. M. (2010). Finance-investment-growth nexus in South Africa: an ARDL-bounds testing procedure. Economic Change and Restructuring, 43(3), 205-219. https://doi.org/10.1007/s10644-010-9085-5

Osaseri, G., \& Osamwonyi, I. O. (2019). Impact of Stock Market Development on Economic Growth in Bricks. International Journal of Financial Research, 10(1), 23-30. https://doi.org/10.5430/ijfr.v10n1p23

Pesaran, M. H., Shin, Y., \& Smith, R. J. (2001). Bounds testing approaches to the analysis of level relationships. Journal of Applied Econometrics, 16(3), 289-326. https://doi.org/10.1002/jae.616

Petros, J. (2012). The effect of the stock exchange on economic growth: a case of the Zimbabwe stock exchange. Research in Business and Economics Journal, $6, \quad 1$. https://citeseerx.ist.psu.edu/viewdoc/download?d $\mathrm{oi}=10.1 .1 .1065 .8560 \& \mathrm{rep}=\mathrm{rep} 1 \&$ type $=\mathrm{pdf}$

Popoola, O. R., Ejemeyovwi, O. J., Philip, A. O., Adu, O., \& Ademola, O. A. (2017). Stock market and economic growth in Nigeria. International Journal of English Literature and Social Sciences, 2(6), 97-106. https://doi.org/10.24001/ijels.2.6.15
Qamruzzaman, M., \& Wei, J. (2018). Financial innovation, stock market development and economic growth: An application of ARDL model. International Journal of Financial Studies, 6(3), 69. https://doi.org/10.3390/ijfs6030069

Robinson, J. (1952). The Generalization of the General Theory, in: The Rate of Interest and Other Essays (MacMillan, London).

Rousseau, P. L., \& Wachtel, P. (2000). Equity markets and growth: Cross-country evidence on timing and outcomes, 1980-1995. Journal of Banking \& Finance, 24(12), 1933-1957. https://doi.org/10.1016/S03784266(99)00123-5

Ruwaydah, A., \& Ushad, S. A. (2015). Effects of stock market development on economic growth: the case of SADC countries. In Proceedings of the Third Middle East Conference on Global Business, Economics, Finance and Banking (ME15Dubai October Conference). http://globalbizresearch. org/Dubai_Conference2015_Oct/pdf/DF501. pdf.

Schumpeter, J.A. (1911). The Theory of Economic Development. Harvard University Press, Cambridge.

Seetanah, B., Sawkut, R., \& Sannasee, V. (2008). Stock Market Development and Economic Growth in Developing countries: Evidence from Panel VAR framework. http://www.csae.ox.ac.uk/conferences/2010EDiA/papers/041-Seetanah.pdf

Shrestha, M. B., \& Bhatta, G. R. (2018). Selecting appropriate methodological framework for time series data analysis. The Journal of Finance and Data Science, $4(2), \quad 71-89$. https://doi.org/10.1016/j.jfds.2017.11.001

Simwaka, K., Munthali, T., Kabango, G., \& Chiumia, A. (2012). Financial development and economic growth in Malawi: an empirical analysis. Banks and Bank Systems, 7(3), 85-96. https://businessperspectives.org/images/pdf/applicati ons/publishing/templates/article/assets/4872/BBS_e n_2012_3_Simwaka.pdf

Solow, R. M. (1956). A contribution to the theory of economic growth. The Quarterly Journal of Economics, 70(1), 65-94. https://doi.org/10.2307/1884513

Tsaurai, K. (2016). The nexus between stock market development and economic growth. https://doi.org/10.22495/cocv14i1c1p10

Zivengwa, T., Mashika, J., Bokosi, F. K., \& Makova, T. (2011). Stock market development and economic growth in Zimbabwe. International Journal of Economics and Finance, 3(5), 140-150. https://doi.org/10.5539/ijef.v3n5p140 